\title{
Pemanfaatan Kotoran Sapi untuk Budidaya Cacing Tanah dan Produksi Vermikompos di Wonoharjo Girimulyo Kabupaten Bengkulu Utara
}

\author{
Urip Santoso $^{1}$, Jarmuji ${ }^{2}$, Bieng Brata ${ }^{3}$ \\ ${ }^{123}$ Jurusan Peternakan, Fakultas Pertanian, Universitas Bengkulu \\ E-mail: e-mail: santoso@unib.ac.id
}

Article History:
Received: Oktober
Revised: Oktober
Accepted: November
Available online: Desember

Kata Kunci: cacing tanah, kelapa sawit, vermikompos

\begin{abstract}
Abstrak:
Masalah petani di Desa Wonoharjo, Kecamatan Girimulya adalah tingginya pencemaran akibat penumpukan kotoran sapi. Tujuan pengabdian masyarakat ini adalah mengenalkan konversi kotoran sapi menjadi vermikompos. Tahapan kegiatannya adalah sosialisasi, pelatihan, demplot, uji coba lapangan dan evaluasi. Pada tahap sosialisasi diperkenalkan pemanfaatan kotoran sapi untuk pembuatan vermikompos. Pada tahap pelatihan dilakukan demplot vermikompos. Uji lapang vermikompos yang dihasilkan dilakukan dengan menguji 30 bibit kelapa sawit yang dibagi menjadi tiga kelompok, yaitu kelompok 1 vermikompos, kelompok 2 pupuk kandang dan kelompok 3 NPK. Hasil penelitian menunjukkan bahwa petani tertarik untuk membuat vermikompos. Vermikompos dapat digunakan sebagai pupuk untuk bibit kelapa sawit pengganti NPK. Bisnis vermikompos memberikan penghasilan tambahan bagi petani. Jadi, pengabdian pada masyarakat memotivasi petani untuk menggunakan vermikompos.
\end{abstract}




\section{Pendahuluan}

Kelompok Tani-ternak di Desa Wonoharjo, Kecamatan Girimulya merupakan kelompok peternak yang memelihara sapi di areal perkebunan kelapa sawit. Terdapat dua kelompok tani-ternak yang cukup kuat dan berkembang di Wonoharjo. Setiap kelompok tani-ternak ini beranggotakan 20 kepala keluarga. Anggota kelompok ini memiliki lahan kelapa sawit berdekatan (hamparan) dan ternak sapi. Kepemilikan ternak sapi anggota kelompok tani-ternak Desa Wonoharjo diperoleh melalui pola gaduan dari pemerintah Kabupaten Bengkulu Utara melalui Program Bantuan Langsung Masyarakat (BLM). Setiap anggota kelompok rata-rata mendapat gaduhan 2 ekor ternak sapi. Populasi awal ternak sapi yang digadukan kelompok peternak Desa Wonoharjo sebanyak 40 ekor sapi dara (siap kawin) pada periode Agustus 2012, namun hingga saat ini populasi bekembang menjadi 98 atau bertambah sebanyak 48 ekor sapi dengan rincian 40 ekor sapi induk, 18 sapi jantan, 15 sapi dara dan 15 ekor anak sapi (pedet) atau setiap anggota kelompok rata-rata memiliki 2-3 ekor ternak sapi. Jenis sapi yang dipelihara adalah bangsa sapi Bali (Monografi Desa, 2015).

Pemeliharaan ternak dilakukan dengan cara ternak sapi dipelihara di dalam kandang sepanjang waktu, namun demikian kotoran ternak hanya dibiarkan menumpuk di sekitar kandang, sehingga menimbulkan polusi yang tinggi. Rata-rata produksi kelapa sawit milik anggota kelompok Desa Wonoharjo juga rendah, yaitu hanya 15 ton/hektar atau rata-rata 1.25 ton/bulan. Sementara rata-rata produksi tanaman kelapa sawit milik perusahaan perkebunan mencapai 27 ton/tahun. Produksi yang rendah ini disebabkan oleh dosis pemberian pupuk yang akibat terbatasnya kebutuhan stok pupuk kimia dipasaran dan harga pupuk yang mahal. Pada sisi lain, petani belum memiliki pengetahuan teknologi pembuatan vermikompos yang dapat digunakan untuk pupuk pada kebun kelapa sawit.

Kebun kelapa sawit dan sapi dapat diintegrasikan dalam suatu sistem integrasi. Bangun (2010) melaporkan bahwa pendapatan petani yang mengintegrasikan kelapa sawit dan sapi jauh lebih tinggi daripada yang tidak terintegrasi. Faktor internal dalam sistem integrasi ini adalah kotoran sapi digunakan sebagai pupuk untuk kelapa sawit, adanya biomassa untuk pakan sapi dan sapi sebagai tabungan. Sistem integrasi ini akan lebih berdaya guna apabila sistem ini lebih dioptimalkan dengan memanfaatkan kotoran sapi sebagai media budidaya cacing tanah.Kotoran sapi merupakan media yang sangat baik untuk pertumbuhan cacing tanah (Brata, 2008). 
Permasalahan mitra yang utama adalah kotoran ternak masih menjadi masalah yang serius karena hanya dibiarkan menjadi limbah di sekitar kandang, lebih-lebih pada saat hari hujan kotoran ternak tersebut akan mengeluarkan bau yang tidak sedap dan berpotensi menjadi masalah sosial. Pengolahan kotoran ternak menjadi pupuk organik yang dilakukan secara konvensional, yaitu dengan cara membiarkan kotoran ternak begitu saja (proses dekomposisi berjalan alami) sampai terbentuk pupuk tidak efektif karena pengeluaran biaya tenaga kerja tidak sebanding dengan hasil yang diharapkan. Proses ini memakan waktu cukup lama dan banyak unsur hara yang hilang tercuci oleh air hujan maupun udara. Pembuatan pupuk kandang dapat dipersingkat dan diminimimalkan tingkat polusinya dengan menggunakan cacing tanah dan mikrobia efektif (Pangaribuan et al., 2012). Permasalahan yang harus segera diatasi dalam meningkatkan produksi kelapa sawit adalah bagaimana menyediakan pupuk yang memiliki unsur hara tinggi, biaya murah, ramah lingkungan dan dapat disediakan oleh petani ternak itu sendiri. Kotoran sapi sangat cocok untuk dibuat pupuk organik karena kaya akan nutrisi yang dibutuhkan oleh kelapa sawit yaitu nitrogen, fosfor dan kalium serta mineral lainnya (Budiyanto, 2011). Selanjutnya dinyatakan bahwa potensi kotoran ternak untuk mendukung pertanian organik di Indonesia sangat tinggi. Di masa yang akan datang, pertanian organik akan menjadi kebutuhan yang mendesak karena tingginya kesadaran masyarakat akan kesehatan (Mayrowani, 2012).

Solusi yang ditawarkan dan telah dibicarakan dengan kelompok tani Desa Wonoharjo dalam mengatasi mahalnya pupuk kimia dan polusi akibat kotoran sapi adalah pemanfaatan kotoran sapi untuk menghasilkan vermikompos.

Ada beberapa teknologi pemanfaatan mikroorganisme yang dapat digunakan untuk mengolah kotoran ternak menjadi pupuk misalnya EM4 (Santoso et al., 2004), fermentasi (Santoso et al., 2015) dan lain-lain. Namun penggunaan bahan-bahan tersebut memiliki keterbatasan seperti harganya relatif mahal, penerapan teknologi pengembangbiakan mikroorganisme terbatas pada skala laboratorium dan penerapan teknologi pembuatan bahanbahan tersebut sulit dilakukan oleh masyarakat petani yang memiliki pendidikan rendah. Hasil disertasi anggota tim pelaksana, Brata (2003) melaporkan bahwa cacing tanah yang sifat utamanya sebagai perombak (composer) mampu memproses kotoran ternak dalam jumlah yang besar. Cacing tanah terbukti mampu merombak bahan organik yang ada pada kotoran sapi menjadi vermikompos yang kaya unsur hara dengan waktu yang relatif singkat. Kemampuan cacing tanah dalam mengurai bahan organik 3-5 kali 
lebih cepat dibanding mikroba atau pengurai lainnya dengan kualitas pupuk organik lebih baik. Jarmuji et al. (2015) juga telah mengembangkan teknologi pengembangan kascing (kotoran cacing tanah) sebagai pupuk organik. Luaran yang ditargetkan adalah pupuk organik berupa kotoran cacing (kascing). Kascing akan digunakan sebagai pupuk pada tanaman kelapa sawit, sehingga diharapkan produktivitas kelapa sawit meningkat.

\section{Metode}

Sebelum mengusulkan kegiatan penerapan Ipteks, terlebih dahulu pengusul telah melakukan survei beberapa kali ke masyarakat Desa Wonoharjo yang merupakan masyarakat yang rata-rata memelihara sapi Bali dan bekerja di kebuh sawit. Dengan melihat data-data desa dan dibantu dengan pihak penyuluh pertanian dengan ditindaklanjuti dengan mendatangi langsung ke lapangan akhirnya pengusul program Ipteks mendapatkan sasaran strategis, yaitu kelompok tani Desa Wonoharjo di kelompok akhirnya terjadi kesepakatan bekerja sama dengan tim Ipteks bagi Masyarakat (IbM). Sebanyak 20 keluarga sebagai anggota kelompok tani-ternak Desa Wonoharjo dan 5 orang tokoh masyarakat dipilih dalam pengenalan teknologi yang ditawarkan. Dari 25 orang ini kemudian diharapkan dapat memberikan informasi/pengetahuan tentang penerapan teknologi budidaya cacing tanah penghasil vermikompos kepada anggota kelompoknya, sehingga seluruh anggota kelompok petani ternak termotivasi untuk dapat menerapkan secara mandiri.

\section{Partisipasi Mitra}

Mitra berperan dalam pemberian informasi yang terkait dengan usaha sapi, kebun kelapa sawit dan permasalahan yang dihadapi oleh mereka, dan apa yang telah dilakukan untuk mengatasi permasalahan tersebut. Informasi ini sangat penting untuk menentukan secara bersama (antara tim pengusul dan mitra) untuk menentukan bentuk kegiatan yang dibutuhkan. Dalam tahap pelaksanaan, mitra berkomitmen untuk memberikan fasilitas yang dibutuhkan dalam kegiatan IbM seperti lahan, kebun kelapa sawit, tempat untuk kegiatan sosialisasi, pelatihan dan demplot. Selain itu, mitra juga berkomitmen untuk mengembangkan Iptek yang dikenalkan dalam usaha mereka. 


\section{Tahapan Pelaksanaan}

Tahapan berikutnya meliputi sosialisasi kegiatan, pelatihan, praktek langsung (demplot) dan uji lapang

1. Sosialisasi Kegiatan

Pada tahapan ini diarahkan untuk memberikan persamaan pemahaman mengenai maksud dan tujuan kegiatan, prosedur untuk implementasi kegiatan serta jaminan keberlanjutan dari kegiatan ini. Agar kegiatan ini dapat berjalan dengan baik dan diterima oleh anggota kelompok maka langkah ini sangat diperlukan. Sosialisasi dilakukan dengan cara memberikan penjelasan kepada kelompok sasaran (ketua kelompok dan tokoh masyarakat) tentang pentingnya teknologi memelihara sapi di perkebunan kelapa sawit, pemanfaatan pelepah sawit sebagai pakan ternak sapi pengganti rumput dan teknologi pemanfaatan kotoran ternak sebagai pupuk dengan menggunakan cacing tanah. Supaya dapat diterima dan dipahami dengan jelas maka pada tahap ini diberi kesempatan diskusi dan tanya jawab. Waktu yang diperlukan pada tahapan ini selama \pm 1 bulan.

2. Pelatihan

Berkaitan dengan pemanfaatan kotoran ternak menjadi vermikompos, pelatihan diberikan berupa (a) cara menyiapkan media berupa kotoran ternak dan serasah (kelembapan, suhu, PH dan kandungan bahan tercemar), (b) cara memilih bibit yang baik, (c) cara penebaran bibit ke dalam media, (d) cara pemeliharaan (pemberian pakan dan menjaga kelembapan dan suhu lingkungan, (e) cara mengganti media, (f) cara mengatasi dan mencegah hama, (g) cara pemanenan dan penanganan pasca panen dan (h) aplikasi pemberian pupuk organik cacing pada tanaman kelapa sawit. Waktu yang dibutuhkan dalam pelatihan teknologi pemanfaatan kotoran ternak menjadi pupuk organik \pm 7 hari.

Guna menghindari jadwal kegiatan rutin petani terutama saat panen kelapa sawit alokasi waktu yang disediakan untuk kegiatan ini selama 2 bulan.

3. Demplot

Demplot budidaya cacing tanah penghasil vermikompos dilakukan dengan membangun kandang pemeliharaan cacing tanah. Kandang cacing tanah dibuat di 2 lokasi di Desa Wonoharjo untuk menjangkau peserta pengabdian. Kandang kandang cacing dibuat sebanyak 4 buah berjejer, dan ukuran petak adalah $1 \times 2 \mathrm{~m}$. 
Uji lapang terhadap teknologi pemanfaatan penggunaan vermikompos dilakukan dengan menguji 30 batang bibit tanaman sawit (main nursery) yang terbagi atas 3 kelompok (masing-masing kelompok 10 batang). Kelompok 1 bibit kelapa sawit yang diberi pupuk kimia, kelompok 2 bibit sawit yang diberi kompos dan kelompok 3 bibit sawit yang diberi vermikompos. Tujuan tahapan ini adalah agar petani dapat melihat langsung pengaruh pemberian pupuk organik cacing yang dibandingkan dengan kompos (konvensional) dan pupuk kimia terhadap tanaman kelapa sawit.

5. Evaluasi dan Kelanjutan Program Pengabdian pada Masyarakat

Kemajuan pekerjaan di lapangan dipantau dengan cara kunjungan langsung tim pelaksana ke lokasi, yaitu di kelompok tani Desa Wonoharjo, Kecamatan Girimulyo, Kabupaten Bengkulu Utara. Selain itu, koordinasi dengan anggota tim Penyuluh Pertanian Kecamatan Girimulyo, kepala desa, anggota kelompok secara teratur dilakukan untuk memantau pelaksanaan kegiatan. Jarak antara Perguruan Tinggi dan mitra yang relatih dekat $( \pm 60 \mathrm{Km})$ memungkinkan untuk melakukan pemantauan secara intensif.

Pemantauan pemanfaatan produk IbM yang berupa kandang cacing dan peralatannya diserahkan kepada kelompok tani Desa Wonoharjo. Kandang cacing pada saat kegiatan diharapkan dapat digulirkan kepada anggota kelompok yang lain dengan cara mengangsur sesuai dengan biaya yang dikeluarkan. Demikian juga dengan bibit cacing, setelah berkembang biak kemudian digulirkan kepada anggota kelompok tani yang lain. Perguliran ini terus berlanjut sampai seluruh anggota kelompok tani di desa Wonoharjo dapat menerapkan teknologi tersebut. Melalui Kerja sama antara Jurusan Peternakan Universitas Bengkulu, Penyuluh Pertanian Kecamatan Girimulyo Kabupaten Bengkulu Utara dan aparat desa terus merintis dan melakukan upaya-upaya untuk meningkatkan kinerja kelompok petani tenak dengan melakukan pendampingan.

Sesuai dengan beberapa permasalahan dan rencana kegiatan yang dilakukan di kelompok tani Desa Wonoharjo, setidaknya ada 2 target luaran, yaitu:

1) Kotoran ternak diubah menjadi vermikompos dengan bantuan cacing tanah yang kaya dan lengkap dengan unsur hara dan hormon pertumbuhan. Hasil penelitian Anwar (2009) bahwa cacing tanah sangat efektif dalam mendekomposisi bahan organik. Cacing tanah juga berperan dalam penurunan rasio $\mathrm{C} / \mathrm{N}$ bahan organik dan 
mengubah nitrogen tidak tersedia menjadi nitrogen tersedia setelah dikeluarkan sebagai kotoran (kascing).

2) Keuntungan lain yang diperoleh petani adalah produk cacing tanah yang selama ini dipercaya dan terbukti menjadi obat beberapa penyakit seperti tifus, karena mampu menghambat Salmonella typhi (Harmatang, 2011), kulit dan gangguan pencernaan serta menjadi minuman (jus) yang menyehatkan. Hal ini diperkuat oleh hasil penelitian Julendra dan Sofyan (2007) bahwa cacing tanah bersifat antibakteri, dan dapat menghambat pertumbuhan Escherichia coli, dan meningkatkan kekebalan tubuh hewan. Produk cacing juga dapat dimanfaatkan sebagai bahan pakan sumber protein untuk pakan ikan (Zakaria et al., 2012) dan ternak unggas (Damayanti et al., 2009) di sekitar lokasi kelompok tani ternak Desa Wonoharjo.

\section{Hasil}

Hasil pengabdian, masyarakat sangat tertarik untuk membudidayakan cacing tanah untuk diambil vermikompos dan sekaligus produksi cacing tanah. Hasil vermikompos dan cacing tanah yang diperoleh selama 3 bulan adalah masing-masing sebanyak 1,5 ton vermikompos dan $30 \mathrm{~kg}$ cacing tanah. Ada dua kandang budidaya cacing tanah sebagai percontohan. Vermikompos yang dihasilkan digunakan untuk pupuk pada bibit kelapa sawit. Permasalahannya adalah pemasaran cacing tanah yang diproduksi belum ada. Ketertarikan ini terbukti, semua peternak meminta wadah kecil (berupa ember) untuk berlatih budidaya cacing tanah.

Sosialisasi Kegiatan

Sosialisasi kegiatan dilakukan beberapa kali sejak bulan Maret 2017. Tujuannya adalah untuk menyamakan persepsi kegiatan pengabdian pada masyarakat.

Pelatihan

Pelatihan tentang pemanfaatan kotoran ternak menjadi vermikompos. Pelatihan yang diberikan berupa (a) cara menyiapkan media berupa kotoran ternak dan serasah (kelembaban, suhu, PH dan kandungan bahan tercemar), (b) cara memilih bibit cacing tanah yang baik, (c) cara penebaran bibit ke dalam media, (d) cara pemeliharaan (pemberian pakan dan menjaga kelembapan dan suhu lingkungan, (e) cara mengganti media, (f) cara pemanenan dan penanganan pasca panen dan $(\mathrm{g})$ aplikasi pemberian pupuk 
organic cacing pada tanaman kelapa sawit.

Tabel 1 menunjukkan hasil tes sebelum dan sesudah pelatihan. Sebelum pelatihan mereka belum tahun teknologi vermikompos. Yang mereka ketahui adalah pembuatan pupuk kandang, yang kadang diterapkan untuk pupuk kelapa sawit. Sesudah pelatihan, mereka memahami dan tertarik untuk membuat vermikompos.

Tabel 2 menunjukkan tingkat keterampilan akhir peserta pengabdian. Dari Tabel 2 dapat dilihat bahwa tingkat keterampilan praktek budidaya cacing tanah untuk menghasilkan vermikompos sebesar 60\%. Sementara praktek penggunaan vermikompos untuk bibit sawit belum ada peserta yang mencobanya. Pada akhir pengabdian, semua peserta mengetahui penggunaan kotoran sapi untuk budidaya cacing tanah dan pembuatan vermikompos, dan mengetahui penggunaan vermikompos untuk pupuk tanaman kelapa sawit.

Tabel 1. Tingkat keterampilan awal program kegiatan pengabdian

\begin{tabular}{lcc}
\hline Parameter & Sebelum Kegiatan & Sesudah Kegiatan \\
\hline $\begin{array}{l}\text { Tahu tentang } \\
\text { vermikompos }\end{array}$ & 0 & 100 \\
\hline $\begin{array}{l}\text { Pernah terlibat dalam } \\
\text { budidaya cacing tanah }\end{array}$ & 0 & 100 \\
\hline $\begin{array}{l}\text { Pernah terlibat dalam } \\
\text { pembuatan } \\
\text { vermikompos }\end{array}$ & 0 & 100 \\
\hline $\begin{array}{l}\text { Ketertarikkan } \\
\text { penggunaan kotoran } \\
\text { sapi untuk } \\
\text { vermikompos }\end{array}$ & 0 & 100 \\
\hline $\begin{array}{l}\text { Mengetahui teknik } \\
\text { pembuatan } \\
\text { vermikompos }\end{array}$ & 0 & 100 \\
\hline $\begin{array}{l}\text { Keinginan pemanfaatan } \\
\text { kotoran sapi untuk } \\
\text { vermikompos }\end{array}$ & 0 & 100 \\
\hline
\end{tabular}


Tabel 2. Tingkat keterampilan akhir peserta pengabdian

\begin{tabular}{lc}
\hline Parameter & Nilai (1-100) \\
\hline $\begin{array}{l}\text { Tahu penggunaan kotoran sapi } \\
\text { untuk budidaya cacing tanah }\end{array}$ & 100 \\
\hline $\begin{array}{l}\text { Tahu penggunaan kotoran sapi } \\
\text { untuk pembuatan vermikompos }\end{array}$ & 100 \\
\hline $\begin{array}{l}\text { Tahu penggunaan vermikompos } \\
\text { untuk pupuk pada bibit kelapa sawit }\end{array}$ & 100 \\
\hline $\begin{array}{l}\text { Praktek budidaya cacing tanah } \\
\text { untuk vermikompos }\end{array}$ & 60 \\
\hline $\begin{array}{l}\text { Kepuasan terhadap program } \\
\text { pengabdian pada masyarakat }\end{array}$ & 100 \\
$\begin{array}{l}\text { Praktek penggunaan vermikompos } \\
\text { untuk pupuk bibit sawit }\end{array}$ & 0 (belum dipraktekkan) \\
\hline $\begin{array}{l}\text { Keinginan penggunaan } \\
\text { vermikompos untuk bibit sawit }\end{array}$ & 100 \\
\hline
\end{tabular}

Demplot

Demplot pertama adalah budidaya cacing tanah. Untuk itu telah dibuat kandang cacing tanah sebanyak 2 buah, sehingga masing-masing kelompok mendapat 1 kandang. Untuk 1 kandang disebar bibit cacing tanah sebanyak $2,5 \mathrm{~kg}$, sehingga total bibit untuk 2 kandang sebanyak $5 \mathrm{~kg}$. Petani lainnya mengusulkan untuk berlatih budidaya cacing tanah dalam skala kecil. Untuk itu mereka disediakan ember untuk budidaya cacing tanah.

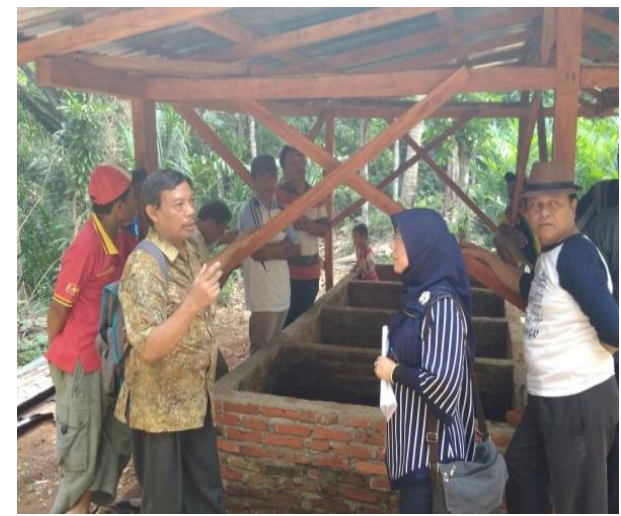

Gambar 1. Kandang cacing tanah

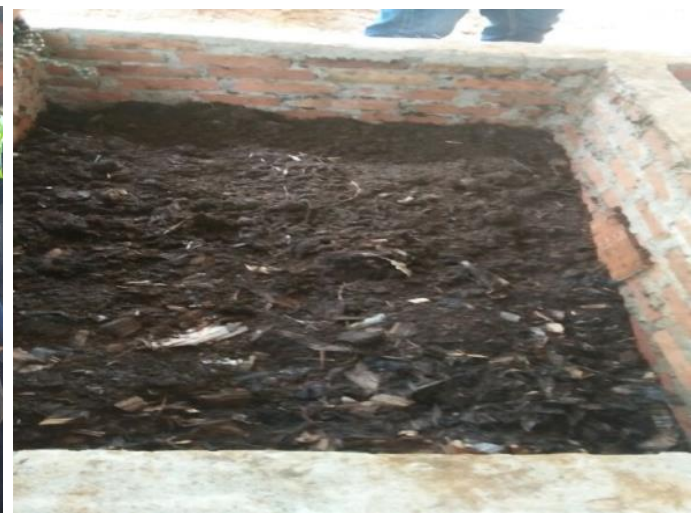

Gambar 2. Vermikompos 
Hasil demplot yang membandingkan antara pupuk sintetis (NPK), pupuk kandang dan vermikompos yang digunakan untuk memupuk bibit sawit menunjukkan bahwa pertumbuhan bibit sawit pada kelompok yang diberi pupuk sintetik, pupuk kandang dan vermikompos menghasilkan tinggi kelapa sawit yang sama, yaitu $21 \mathrm{~cm}$ dengan perakaran yang baik.

\section{Analisis Pendapatan}

Petani di Desa Wonoharjo menghasilkan pupuk kandang sebanyak 1,5 ton dalam waktu 3 bulan. Hasil demplot dalam 3 bulan menghasilkan 1,5 ton vermikompos. Meskipun menghasilkan pupuk yang relatif sama, harga vermikompos lebih tinggi ( Rp 1.500/kg) daripada pupuk kandang (Rp 500). Selain itu pada vermikompos juga dihasilkan $30 \mathrm{~kg}$ cacing tanah dalam waktu 3 bulan. Jika dikonversikan dalam bulan, maka vermikompos juga menghasilkan $10 \mathrm{~kg}$ cacing tanah/bulan. Harga cacing tanah di pasar adalah Rp 100.000/kg. Tabel 3 menyajikan analisis pendapatan dari dua jenis pupuk.

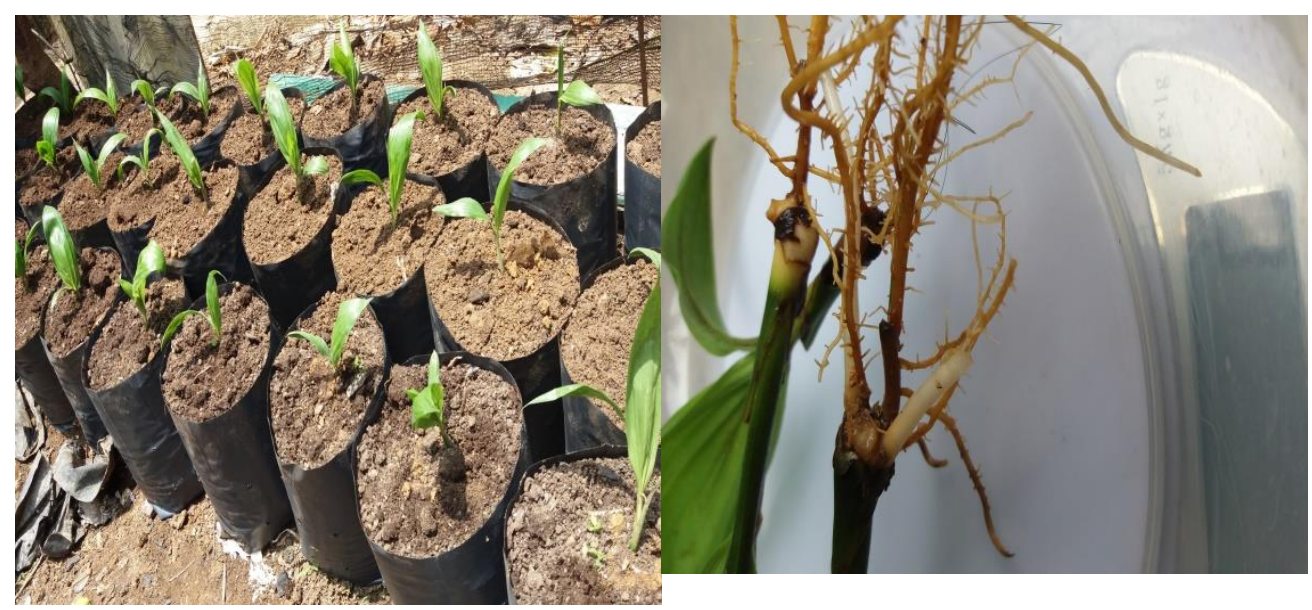

Gambar 3. Demplot vermikompos

Gambar 4. Perakaran bibit sawit 
Tabel 3. Analisis pendapatan

\begin{tabular}{lll}
\hline & Pupuk Kandang & Vermikompos \\
\hline Biaya & & \\
\hline Bibit cacing tanah 5 kg & & $\mathrm{Rp} \mathrm{500.000}$ \\
\hline Tenaga kerja/bulan & $\mathrm{Rp} \mathrm{45.000}$ & $\mathrm{Rp} \mathrm{200.000}$ \\
\hline Penyusutan alat/bulan & $\mathrm{Rp} \mathrm{5.000}$ & $\mathrm{Rp} \mathrm{5.000}$ \\
\hline Total biaya/bulan & $\mathrm{Rp} \mathrm{50.000}$ & $\mathrm{Rp} \mathrm{705.000}$ \\
\hline Pendapatan & & \\
\hline Cacing tanah 10 kg/bulan & & $\mathrm{Rp} \mathrm{1.000.000}$ \\
\hline Pupuk yang dihasilkan/bulan & $500 \mathrm{~kg}$ & $500 \mathrm{~kg}$ \\
\hline Harga pupuk & $\mathrm{Rp} \mathrm{500}$ & $\mathrm{Rp} \mathrm{1500}$ \\
\hline Pendapatan dari pupuk/bulan & $\mathrm{Rp} \mathrm{250.000}$ & $\mathrm{Rp} \mathrm{750.000}$ \\
\hline Total pendapatan kotoran/bulan & $\mathrm{Rp} \mathrm{250.000}$ & $\mathrm{Rp} \mathrm{1.750.000}$ \\
\hline Pendapatan bersih/bulan & $\mathrm{Rp} \mathrm{200.000}$ & $\mathrm{Rp} \mathrm{1.045.000}$ \\
\hline
\end{tabular}

Pendapatan bersih pupuk kandang adalah sebesar Rp 200.000/bulan, sedangkan vermikompos sebesar $\mathrm{Rp}$ 1.045.000. Jadi vermikompos menghasilkan tambahan pendapatan sebesar Rp 845.000/bulan.

\section{Diskusi}

Selama sosialisasi peserta pengabdian menyatakan bahwa terdapat permasalahan jika ada pertanyaan dari LSM tentang kegiatan tersebut. Jika ada LSM yang datang menanyakan kegiatan ini, maka peternak disarankan untuk menjelaskan bahwa kegiatan ini adalah kegiatan Universitas Bengkulu. Segala bentuk pertanyaan dari pihak LSM akan dijawab oleh tim IbM. Penjelasan ini membuat peserta pengabdian menjadi mantap untuk mengikuti pengabdian masyarakat tersebut.

Pada awal pengabdian para peserta belum mengetahui tentang teknologi vermikompos. Setelah pelatihan mereka sangat tertarik untuk mempraktekkannya. Meskipun tim menjelaskan bahwa ada 2 kandang percobaan untuk praktek pembuatan vermikompos, tapi mereka kurang puas. Mereka bermaksud untuk praktek dalam skala yang kecil. Untuk itu mereka meminta disediakan ember kecil untuk praktek pembuatan vermikompos. 
Terjadi peningkatan pengetahuan dari peserta pengabdian terutama dalam hal budidaya cacing tanah untuk menghasilkan vermikompos dan penggunaan vermikompos sebagai pupuk kelapa sawit. Peningkatan pengetahuan sangat penting bagi peningkatan motivasi, keterampilan dan perbaikkan usaha kebun kelapa sawit dan pada akhirnya meningkatkan kinerja mereka. Mazdayani et al. (2014) melaporkan bahwa pengetahuan, keterampilan dan motivasi akan meningkatkan kinerja seseorang/kelompok orang. Peningkatan kinerja ini pada akhirnya akan meningkatkan pendapatan petani kelapa sawit.

Hasil demplot penggunaan vermikompos menunjukkan bahwa vermikompos dapat menggantikan pupuk buatan dan menghasilkan petumbuhan bibit kelapa sawit yang relatif sama. Pemberian vermikompos 20 $\mathrm{g} /$ bibit memberikan serapan nitrogen yang paling tinggi (Manahan et al., 2016). Selanjutnya dinyatakan bahwa tinggi bibit sawit yang diberi vermikompos lebih tinggi daripada bibit yang diberi pupuk NPK.

Hasil analisis ekonomi menunjukkan bahwa vermikompos menghasilkan pendapatan yang lebih tinggi jika dibandingkan dengan pupuk kandang. Sementara cacing yang dihasilkan juga dapat dimanfaatkan untuk pakan ayam, obat atau keperluan lainnya. Pada saat pengabdian, ada penduduk yang minta cacing tanah tersebut untuk mengobati penyakit tipes yang diderita anaknya, dan ternyata anak tersebut sembuh. Permasalahannya adalah belum ada pasar untuk menjual cacing tanah yang dihasilkan. Untuk sementara cacing tanah yang dihasilkan dibagikan kepada penduduk untuk bibit pada budidaya cacing tanah untuk menghasilkan vermikompos.

\section{Kesimpulan}

Hasil demplot menunjukkan bahwa vermikompos dapat digunakan sebagai pupuk pada bibit kelapa sawit dan jika diproduksi dalam jumlah besar dapat digunakan untuk pupuk kebun kelapa sawit. Petani sangat tertarik untuk mengolah kotoran sapi menjadi vermikompos yang akan digunakan untuk pupuk kebun kelapa sawitnya. Kegiatan ini membutuhkan partisipasi Pemerintah Daerah Bengkulu Utara dan swasta agar kegiatan ini dapat berkesinambungan. 


\section{Pengakuan/Acknowledgements}

Penulis mengucapkan terima kasih kepada Direktorat Riset dan Pengabdian Masyarakat, Direktorat Jenderal Penguatan Riset dan Pengembangan, Kementerian Riset, Teknologi, dan Pendidikan Tinggi, yang telah mendanai pengabdian pada masyarakat ini, sesuai dengan Perjanjian Penugasan Pelaksanaan Program Pengabdian Masyarakat Nomor: 031/SP2H/PPM/DRPM/IV/2017, tanggal 3 April 2017.

\section{Daftar Referensi}

Anwar, E. K. 2009. Efektivitas caing tanah Pheretima hupiensis, Edrellus sp, dan Lumbricus sp dalam proses dekomposisi bahan organik. J. Tanah Trop. 14 (2): 149-158.

Bangun, R. 2010. Analisis Sistem Integrasi Sapi-Kebun Kelapa Sawit dalam Meningkatkan Pendapatan Petani di Kabupaten Rokan Hulu Propinsi Riau. Tesis. Program Pasca Sarjana, Universitas Andalas, Padang.

Brata, B. 2003. Pertumbuhan, Perkembangbiakan dan kualitas Eksmecat dari beberapa spesies Cacing Tanah pada Kondisi Lingkungan yag Berbeda. Disertasi. Pasca Sarjana Institut Pertanian Bogor.

Brata, B. 2008. Kualitas eksmecat dari beberapa spesies cacing tanah pada tingkat penyiraman dan pengapuran yang berbeda. JSPI, 3 (1): 43-48.

Budiyanto, M. A. K. 2011. Tipologi pendayagunaan kotoran sapi dalam upaya mendukung pertanian organik di desa Sumbersari Kecamatan Poncokusumo Kabupaten Malang. GAMMA 7 (1): 42-49.

Damayanti, E., Sofyan, A., Julendra, H. dan Untari, T. 2009. Pemanfaatan tepung cacing tanah (Lumbricus rebellus) sebagai agensia antipullorum dalam imbunan pakan ayam broiler. JITV, 14 (2): 83-89.

Harmatang, S. 2011. Isolasi dan karakterisasi bakteri simbion pada cacing tanah Pheretima sp dari berbagai substrat. Skripsi. FMIPA, Universitas Hasanuddin, Makassar.

Jarmuji, B. Brata dan U. Santoso. 2015. Penggunaan pelepah sawit dan sakura block pada sapi Kaur dan pemanfaatan feses sapi Kaur sebagai media tumbuh cacing tanah. Laporan Hibah Bersaing Tahun 1, Universitas Bengkulu, Bengkulu.

Julendra, H dan Sofyan, A. 2007. Uji in vitro penghambatan aktivitas Escherichia coli dengan tepung cacing tanah (Lumbricus rubellus. Media Peternakan, 30 (1): 41-47.

Manahan, S., Idwar dan Wardati. 2016. Pengaruh pupuk NPK dan kascing terhadap pertumbuhan kelapa sawit (Elaeis guineensis Jacq) fase main 
nursery. JOM Faperta, 3 (2): 1-10.

Mayrowani, H. 2012. Pengembangan pertanian organik di Indonesia. Forum

Penelitian Agro Ekonomi, 30 (2): 91-108.

Mazdayani, W. D, Sayekti dan A. Nugraha. 2014. Pengaruh pengetahuan,

keterampilan, motivasi dan kompensasi terhadap kinerja mandor sadap

di PT Perkebunan Nusantara VII (Persero). JIIA, 2(3): 295-300.

Monografi Desa. 2015. Profil Desa Wonoharjo, Kecamatan Girimulyo, Kabupaten Bengkulu Utara.

Pangaribuan, D. H., Yasir, M. dan Utami, N. K. 2012. Dampak bokashi kotoran ternak dalam pengurangan pemakaian pupuk anorganik pada budidaya tanaman tomat. J. Agron. Indonesia, 40 (3): 204-210.

Santoso, U., Fenita, Y., Kususiyah and Bidura, I. G. N. G.. 2015. Effect of fermented Sauropus androgynus leaves on meat composition, amino acid and fatty acid compositions in broiler chickens. Pak. J. Nutr. 14:799-807.

Santoso, U. Nengsih, F., Rozal, A., Setianto, J. dan Kadarsih, S. 2004. The effect of fermented feces on growth, fat deposition, and carcass quality in broiler chickens. JITAA, 29 (1): 27-32.

Zakaria, Z., Salleh, N. H. M., Mohamed, A. R., Anas, N. G. A. and Idris, S. N. A.. 2012. Optimization of protein content in earthworm based fish feed formulation for catfish (Clarius gariepinus). Sains Malaysiana, 41 (9): 1071-1077. 